\title{
Melt and rheological properties of Mozzarella cheese as affected by starter culture and coagulating enzymes ${ }^{1}$
}

\author{
Rajiv I. DAVE ${ }^{a *}$, Pragati SHARMA ${ }^{\mathrm{a}}$, Donald J. McMAHON ${ }^{\mathrm{b}}$ \\ a Dairy Science Department, Minnesota-South Dakota Dairy Foods Research Center, \\ South Dakota State University, Box 2104, Brookings, SD 57007, USA \\ ${ }^{b}$ Department of Nutrition and Food Sciences, Western Center for Dairy Protein Research \\ and Technology, Utah State University, Logan UT 84322, USA
}

(Received 6 February 2002; accepted 5 June 2002)

\begin{abstract}
Low moisture part-skim (LMPS) Mozzarella cheeses were made with single culture (SC) of Streptococcus thermophilus or mixed culture (MC) of Streptococcus thermophilus and Lactobacillus helveticus using $1 \times$ or $6 \times$ of cheese coagulants chymosin or Cryphonectria parasitica (CP). Cheeses were analyzed for total solids, fat, protein, ash, salt, and calcium on day 1 . Changes in melt characteristics and proteolysis during storage $\left(4^{\circ} \mathrm{C}\right)$ were monitored on $1,7,15$, and 30 days (d). After $30 \mathrm{~d}$ storage, melt area as measured by modified Schreiber test increased only by approximately 2 times in cheeses made with SC as against 3-4 times in the cheeses made with MC. On d 30, creep test showed that the fall in height decreased by approximately 4-5 times in the SC cheeses but approximately 7-9 times in the cheeses made with MC when compared with the values obtained on $\mathrm{d} 1$ for corresponding cheeses. Melt characteristics on $\mathrm{d} 7$ for cheeses prepared with MC almost corresponded to that of d 30 cheeses made with SC, suggesting faster ripening and increase in melt of cheeses made with MC. Soluble nitrogen was also higher in MC cheeses as compared to those made using SC only. The degradation of total $\alpha_{\mathrm{s}}$-casein was higher in the chymosin cheeses and that of $\beta$-casein in the $\mathrm{CP}$ cheeses. The degradation of casein fraction $\mathrm{f}_{(24-199)}$ was higher in $\mathrm{MC}$ cheeses as compared to those prepared with SC only. After $30 \mathrm{~d}$ storage, the highest percentage breakdown of $\alpha_{\mathrm{s}}$-casein was approximately $75 \%$ in cheeses made with MC using $6 \times$ chymosin and that of $\beta$-casein was approximately $50 \%$ in cheese samples prepared with $\mathrm{MC}$ using $6 \times$ coagulant from Cryphonectria parasitica. Meltability of Mozzarella cheese was better correlated to hydrolysis of $\beta$-casein and was comparable to soluble nitrogen but least to $\alpha_{\mathrm{s}}$-casein.
\end{abstract}

\section{Mozzarella cheese / melt / proteolysis / starter culture / coagulant concentration}

Résumé - Fonte et propriétés rhéologiques de fromage Mozzarella en fonction du levain et des enzymes coagulantes utilisés. Des fromages Mozzarella obtenus à partir de lait partiellement écrémé et à faible teneur en humidité ont été fabriqués avec une culture pure (SC) de Streptococcus thermophilus ou avec une culture mixte (MC) de Streptococcus thermophilus et de Lactobacillus

\footnotetext{
${ }^{1}$ Published with the approval of the director of the South Dakota Agricultural Experiment Station as Publication Number 3290 of the Journal Series.

*Correspondence and reprints

Tel.: (605) 688-6648; fax: (605) 688-6276; e-mail: Rajiv_Dave@sdstate.edu
} 
helveticus en utilisant deux taux $(1 \times$ et $6 \times)$ de chymosine ou d'enzyme coagulante de Cryphonectria parasitica $(\mathrm{CP})$. Les fromages ont été analysés pour leur teneur en matière sèche totale, matière grasse, protéines, cendres, sels et calcium au jour 1. Les changements des caractéristiques de fonte et de la protéolyse au cours du stockage $\left(4^{\circ} \mathrm{C}\right)$ ont été mesurés aux jours $1,7,15$ et 30 . Après $30 \mathrm{j}$ de stockage, la surface de fonte mesurée par le test de Schreiber modifié augmentait seulement de 2 fois pour les fromages avec SC contre 3-4 fois pour les fromages avec MC. Au jour 30 le test de fluage a montré que la diminution de hauteur du fromage a baissé approximativement de 4-5 fois dans les fromages avec SC mais approximativement de 7-9 fois dans les fromages faits avec MC comparativement aux valeurs obtenues au jour 1 pour les fromages correspondants. Les caractéristiques de fonte au jour 7 pour les fromages préparés avec $\mathrm{MC}$ correspondaient presque à celles des fromages avec $\mathrm{SC}$ au jour 30, suggérant un affinage et une augmentation des propriétés de fonte plus rapides des fromages fabriqués avec MC. L'azote soluble était également plus élevé dans les fromages MC comparés à ceux fabriqués avec SC seulement. L'hydrolyse de la caséine $\alpha_{\mathrm{s}}$ totale était plus élevée dans les fromages faits avec la chymosine et celle de la caséine $\beta$ dans les fromages $\mathrm{CP}$. L'hydrolyse de la fraction de caséine $\mathrm{f}_{(24-199)}$ était plus élevée dans les fromages MC en comparaison de ceux préparés avec SC seulement. Après 30 jours de stockage, le pourcentage le plus élevé d'hydrolyse de la caséine $\alpha_{\mathrm{s}}$ était approximativement de $75 \%$ dans les fromages fait avec MC en utilisant une dose de $6 \times$ de chymosine et celui de la caséine $\beta$ était approximativement de $50 \%$ dans les fromages préparés avec MC utilisant $6 \times$ d'enzyme coagulante de Cryphonectria parasitica. L'aptitude à la fonte du fromage Mozzarella était mieux corrélée à l'hydrolyse de la caséine $\beta$, comparablement à l'azote soluble mais moins bien corrélée à l'hydrolyse de la caséine $\alpha_{\mathrm{s}}$.

\section{Fromage Mozzarella / fonte / protéolyse / levain / concentration en enzyme coagulante}

\section{INTRODUCTION}

Mozzarella cheese has become one of the most popular cheese varieties in the USA. It is estimated that approximately $70 \%$ of Mozzarella cheese is used as an ingredient on pizza. Its usage is expected to grow as global interest and demand for pizza and other foods that use Mozzarella cheese increase $[1,21]$. Since most of the Mozzarella cheese is used for pizza, its functionality is of utmost importance. The factors that will affect these characteristics will in turn affect the acceptability of Mozzarella cheese. In a survey, over 50\% of pizza restaurants reported occasional to frequent problems in quality of which $67 \%$ related to melting of Mozzarella cheese [35].

The functional properties of Mozzarella cheese develop in two distinct, but interdependent phases. The first phase occurs during manufacture, when the basic curd structure is established and the second occurs during storage, when functionality and curd structure alter [38]. The functional properties attributed to melted
Mozzarella cheeses are wide and varied, which are largely responsible for consumer perception [38]. Defects associated with Mozzarella cheese include a rubbery, tough texture, lack of flavor, paleness or green tint, inability to melt, and poor stretchability $[15,28,41]$. These functional properties of Mozzarella cheese are influenced by a multitude of factors that include cheese composition, especially the moisture and fat contents, $\mathrm{pH}$, coagulating enzymes, starter culture, homogenization, cooking and stretching, salt content, and the changes occurring during aging and storage [11, 22, 26, 38]. Moisture in cheese acts as a plasticizer and also plays an important role in cheese functionality. The protein matrix/structure also largely affects cheese functionality. As the cheeses mature, casein undergoes both hydration and hydrolysis. This results in the weakening of the structure and an increase in melt of cheese [16]. Factors that affect the hydrolysis of different casein fractions may in turn affect the functional characteristics of Mozzarella cheese. Previous studies have shown that proteolysis in Mozzarella cheese is contributed both by 
the starter culture [31, 32] and coagulating enzymes [9]. Different starter cultures have different proteolytic activity that can influence the functionality of Mozzarella cheese [18, 20, 31, 32]. Lactobacillus helveticus has been reported to give better functional properties, i.e. increase in melt, when used as starter culture with Streptococcus thermophilus as compared to the more traditional $L b$. delbrueckii ssp. bulgaricus [31, 32]. Different coagulating enzymes are also known to have different specificity towards casein [13, 34, 48]. Protease from Cryphonectria parasitica is more proteolytic and specific towards $\beta$-casein compared to chymosin, which is less proteolytic and more specific towards $\alpha_{s}$-casein [48]. Bogenrief and Olson [4] and Olson [34] reported that meltability in Cheddar cheese was more closely related to $\beta$-casein hydrolysis compared to $\alpha_{\mathrm{s}}$-casein hydrolysis. However, information on the relationship between meltability and type of proteolysis is scant for Mozzarella cheese, which is usually not stored for longer periods such as is Cheddar cheese. This study was therefore designed to gain an insight on the effects of starter culture and coagulating enzymes on the melting and rheological properties of Mozzarella cheese. The specific objectives were to study the effects of the type of proteolysis occurring in Mozzarella cheese as a function of starter culture and type and levels of coagulating enzyme and its correlation with rheological and the melting characteristics of Mozzarella cheese.

\section{MATERIALS AND METHODS}

\subsection{Selection of starter culture}

One of the objectives of this study was to investigate the contribution of the starter culture toward proteolysis occurring in the cheese and its effects on the melting and rheological characteristics. S. thermophilus is less proteolytic than lactobacilli and works symbiotically with the latter for faster acid production in yogurt [30, 37]. Therefore, a single culture (SC) of direct vat set (DVS) St. thermophilus (DS134) or a mixed culture (MC) of proteolytic strain of Lb. helveticus (R13V, Utah State University, Logan, UT, USA) as bulk culture and DVS St. thermophilus (DS134) were selected. For cheese making, Lb. helveticus was initially propagated in sterilized skim milk of $110 \mathrm{~g} \cdot \mathrm{kg}^{-1}$ solids and with yeast extract, peptone, and glucose added to activate the culture. The final propagation to obtain bulk culture was in sterilized $\left(121^{\circ} \mathrm{C}\right.$ for $15 \mathrm{~min}$ ) skim milk. Prior to addition to the cheese milk, St. thermophilus (200 mg. $\mathrm{L}^{-1}$ of cheese milk, as recommended by the supplier) was mixed with $L b$. helveticus $\left(10 \mathrm{~g} \cdot \mathrm{L}^{-1}\right)$. For the manufacture of $\mathrm{SC}$ cheeses the rate of starter addition was $800 \mathrm{mg} \cdot \mathrm{L}^{-1}$, because from preliminary trials using 200, 400, 600, 800, and $1000 \mathrm{mg} \cdot \mathrm{L}^{-1}$ of SC, it was determined that $800 \mathrm{mg} \cdot \mathrm{L}^{-1} \mathrm{SC}$ was required in order to have the same rate of acid production in milk as that observed with MC used in this study.

\subsection{Selection of appropriate enzyme level}

Chymosin $\quad\left(\right.$ Chymax ${ }^{\circledR} \quad$ Extra, Chr. Hansen, Milwaukee, WI, USA) and Cryphonectria parasitica protease (Sure curd $^{\circledR} 600$, DSM Food specialties, USA, Inc., Menomonee Falls, WI, USA) were selected as the two coagulating enzymes as they are known to have different specificity towards the casein fractions.

\subsection{Cheese-making}

This study had eight different treatments. Two different cultures, each with two types of coagulating enzymes and two different levels, were used as described earlier. Four replications were carried out on four separate occasions and the treatments were randomly assigned to cheese vats. 
Raw milk procured from the Dairy Training and Research Unit (South Dakota State University, Brookings, SD, USA) was warmed to $40{ }^{\circ} \mathrm{C}$ and centrifugally separated (Model 100AE, De Laval Separator Co., New York, NY, USA). The separated milk was standardized to $1.6 \%$ fat, pasteurized $\left(62.8^{\circ} \mathrm{C}\right.$ for $\left.30 \mathrm{~min}\right)$, and stored at $4{ }^{\circ} \mathrm{C}$ until used. The standardized milk was warmed in a double-jacketed vat to $30{ }^{\circ} \mathrm{C}$ and $15 \mathrm{~kg}$ were transferred to cheese vats that were partly immersed in water in a bigger vat in order to have identical temperature treatments during cheese making. Milk in each of the vats was then warmed to $32{ }^{\circ} \mathrm{C}$ and the starter culture (MC or SC) was added at the rates described in Section 2.1. After a ripening time of $30 \mathrm{~min}$, single strength $\left(100 \mu \mathrm{L} \cdot \mathrm{kg}^{-1}\right.$ cheese milk) chymosin or Cryphonectria parasitica protease was added to the cheese vats and the $\mathrm{pH}$ of milk at the time of renneting was between 6.36 to 6.45 . After another $10 \mathrm{~min}, 6 \times\left(600 \mu \mathrm{L} \cdot \mathrm{kg}^{-1}\right)$ chymosin or Cryphonectria parasitica protease was added. While adding the coagulating enzymes, the enzyme solution was diluted 1:40 times in case of single strength and 1:6 times in case of 6x enzymes (dilution factor for enzyme was different to keep the dilution effect of milk the same due to addition of enzyme-water solution in all the cheese vats). Curd was cut using $1.1 \mathrm{~cm}$ wire knives followed by healing for $10 \mathrm{~min}$, and then cooking to a final temperature of $40{ }^{\circ} \mathrm{C}$ in $45 \mathrm{~min}$. Approximately $1 / 3 \mathrm{rd}$ of the whey was drained and curds were gently stirred until $\mathrm{pH}$ of the whey was around 6.0. At this point, all of the whey was drained. During cheddaring, curds were turned every 20 min until $\mathrm{pH}$ was 5.1 to 5.3. The time to reach this $\mathrm{pH}$ varied in different vats according to the starter culture (single or mixed) used for preparing the cheese. Curd was then milled into cubes of $2 \mathrm{~cm}$ with a knife and salt added to the curd at the rate of $20 \mathrm{~g} \cdot \mathrm{kg}^{-1}$ and left for $15 \mathrm{~min}$ with intermittent mixing. Salted curds were taken in a strainer for stretching and molding, and immersed in hot water $\left(77^{\circ} \mathrm{C}\right)$ containing $0.5 \%$ salt. The heat treatment was kept well controlled and identical in cheeses while stretching to obtain a similar rate of destruction of residual coagulant in all replicates. Curds were kneaded together, stretched, and re-immersed in hot water $\left(77^{\circ} \mathrm{C}\right)$ for a further $120 \mathrm{~s}$. Cheese was stretched unidirectionally, folded, and stretched. It was immersed again into hot water $\left(77^{\circ} \mathrm{C}\right)$ for $30 \mathrm{~s}$, and blocks were made that were immersed in chilled water. Cheese blocks were taken out after $30 \mathrm{~min}$, cut into 4 parts, and vacuum packaged in Cryovac bags (Cryovac Division, W.R. Grace \& Co., Duncan, SC, USA) using a Spiromac vacuum packaging machine $\left(\right.$ Sogevac $^{\circledR}$, Bourg-les-Valence, France) and stored at $4{ }^{\circ} \mathrm{C}$. One of the blocks from each group of cheeses was randomly sampled for analysis on day $1,8,15$, and 30 .

\subsection{Biochemical analysis}

\subsubsection{Cheese composition}

Total solids and fat in cheese were determined using the Mojonnier method $[2,3]$, total protein using the macroKjeldahl method [2] and ash content by heating samples in the Muffle furnace at $535^{\circ} \mathrm{C}$ [2]. Salt in cheese was determined using a sodium electrode attached to an ion analyzer (Model 350, Corning Medical, Medfield, MA, USA) [23]. Calcium was determined using inductively coupled plasma atomic emission spectroscopy [42]. $\mathrm{pH}$ in cheese was measured using a Ross ${ }^{\circledR}$ (Model 8163, Orion Research Inc., Beverly, MA, USA) combination spear tip $\mathrm{pH}$ electrode connected to a Corning $\mathrm{pH}$ meter (Model 320). Acid soluble protein in cheese was determined by the macroKjeldahl method after extracting it with Sharpe's extract [24]. All proteins were calculated by multiplying the nitrogen content by a factor of 6.38 . 


\subsubsection{Capillary elecrophoresis}

The method described by Dave et al. [9] was used to prepare the acid-urea extract of cheese samples, and collected filtrates were stored $\left(-20{ }^{\circ} \mathrm{C}\right)$ until applied to the capillary electrophoresis (CE) column. The "control" for identification of peaks was a milk sample. Capillary electrophoresis was performed on a PACE 2100 system (Beckman Instruments, Inc., Fullerton, CA, USA). The method used by Broadbent et al. [5] for Cheddar cheese was modified for use in Mozzarella cheese as described by Dave et al. [9]. The urea concentration $\left(4 \mathrm{~mol} \cdot \mathrm{L}^{-1}\right)$ and the polymeric additive hydroxy-propyl-methyl cellulose (HPMC, $1 \mathrm{~g} \cdot \mathrm{L}^{-1}$ ) were the same, but citric acid was used for sample digestion instead of phosphoric acid. For analysis, a $75 \mu \mathrm{m} \times 57 \mathrm{~cm}$ hydrophilic coated P1 capillary (Supelco, Bellefonte, PA, USA) was used with a field strength of $316 \mathrm{~V} \cdot \mathrm{cm}^{-1}(18 \mathrm{kV}, 23 \mu \mathrm{A}$ at $38^{\circ} \mathrm{C}$ ). Run buffer and other operational conditions were identical, as reported by Dave et al. [9].

\subsection{Meltability and rheological analysis}

\subsubsection{Modified Schreiber test}

Melting of the cheeses was determined using a modified Schreiber test [29]. Preliminary trials indicated that single culture cheeses did not melt at $90{ }^{\circ} \mathrm{C}$. Therefore the temperature of melting was increased to $125^{\circ} \mathrm{C}$ in our study to melt experimental "control" cheeses and to have better comparison between the treatments. Area $\left(\mathrm{mm}^{2}\right)$ of the melted cheese was measured using image-processing software (HL Image++98, Western Vision Software, Salt Lake City, UT, USA).

\subsubsection{Creep test}

Meltability of cheese was also measured by Creep test using a UW-melt-meter [45].
A sample of cheese $7 \pm 0.1 \mathrm{~mm}$ thick parallel to the fiber axis and approximately $28.5 \mathrm{~mm}$ diameter was heated to $60^{\circ} \mathrm{C}$, and fall in height at 10,20 , and $30 \mathrm{~s}$ was measured under a constant force of $0.36 \mathrm{~N}$. Meltability was expressed as percent change in the height of cheese [45].

\subsection{Statistical analysis}

The experiment was a factorial randomized complete block design with culture, enzyme, and the level of enzyme as the main effects, each having two different levels. Results of the compositional analysis were analyzed using Proc GLM. Data for capillary gel electrophoresis and acid soluble protein were also analyzed using Proc GLM, because the variance was not homogeneous if the data were analyzed using Proc mixed [39].

\section{RESULTS AND DISCUSSION}

\subsection{Composition of cheese}

The average moisture and protein content of cheeses made from SC were lower than in cheese made from MC $(P \leq$ $0.05)$, but the fat, ash, and salt in moisture content were higher $(P \leq 0.05)$ in SC cheeses (Tab. I). There were no differences $(P>0.05)$ in the salt and calcium contents of SC and MC cheeses. There were no differences $(P>0.05)$ in composition of cheeses made with different types and levels of coagulating enzymes. The differences in the moisture content of SC and MC cheeses could be due to the confounding effects of $\mathrm{pH}$, i.e. the differences in the rate of acid production by these two starter cultures. It was observed that the $\mathrm{pH}$ drop below 5.5 was very slow in SC cheeses. This could be due to the acid injury to St.thermophilus restricting further acid development in SC cheeses. The total time (to drop a whey $\mathrm{pH}$ of 5.1 to 5.2) in SC cheeses was 
Table I. Composition ${ }^{1}(\%)$ of single culture (SC) and mixed culture (MC) cheeses ${ }^{2}$.

\begin{tabular}{ccccccccc}
\hline Cheese & Fat & Protein $^{3}$ & Ash & Calcium & Salt & SM $^{4}$ & Moisture & MNFS $^{5}$ \\
\hline SC & $18.79^{\mathrm{a}}$ & $32.53^{\mathrm{a}}$ & $3.53^{\mathrm{a}}$ & 1.04 & 1.05 & $2.44^{\mathrm{a}}$ & $43.23^{\mathrm{a}}$ & $53.21^{\mathrm{a}}$ \\
$\mathrm{MC}$ & $18.37^{\mathrm{b}}$ & $32.94^{\mathrm{b}}$ & $3.27^{\mathrm{b}}$ & 1.01 & 0.97 & $2.12^{\mathrm{b}}$ & $45.64^{\mathrm{b}}$ & $55.91^{\mathrm{b}}$ \\
LSD $^{6}$ & 0.218 & 0.276 & 0.087 & 0.092 & 0.096 & 0.226 & 0.393 & 0.448 \\
\hline
\end{tabular}

a, b Means in columns with no common superscripts differ $(P<0.05)$.

${ }^{1}$ Averages were not significant for the cheeses made with different types and levels of coagulating enzymes.

${ }^{2}$ Mean averaged by culture ( 2 enzymes $\times 2$ levels $\times 4$ replicates).

3 Total protein.

${ }^{4}$ Salt in moisture.

${ }^{5}$ Moisture in non-fat substance.

${ }^{6}$ Least significant difference.

approximately $2-3 \mathrm{~h}$ longer than $\mathrm{MC}$ cheeses. This was not observed in $\mathrm{MC}$ cheeses due to faster acid production by $L b$. helveticus and its continued symbiosis with St. thermophilus. Differences in proteolysis and therefore melt and rheology of cheese can be anticipated due to the differences in moisture in non-fat substances of cheeses. Similar moisture in non-fat substances in cheese could have been obtained by keeping the same cheddaring time in SC and MC cheeses. $\mathrm{SC}$ cheeses took a longer time for acid production compared to MC cheeses, though we increased the rate of addition of starter in SC cheeses. It has been reported that calcium content and $\mathrm{pH}$ of cheese influence functionality of the cheeses [27]. Hence, to keep similar $\mathrm{pH}$ and calcium content in these cheeses, a longer cheddaring time was employed for SC cheeses and this might have led to lower moisture content in these cheeses. Thus, it was not possible to control all the parameters $(\mathrm{pH}$, moisture, and calcium content) in a complex cheese system.

Further, the differences in composition, though small, were statistically significant $(P \leq 0.05)$ because of consistency among replicates. In previous reports [36, 47], cheeses with such differences in moisture (approximately $2 \%$ range) and in other compositional parameters [15] had similar meltability. Therefore, it is reasonable to believe that the differences in melt and rheology of SC or MC cheeses are not solely because of compositional differences.

The average $\mathrm{pH}$ of the experimental cheeses was 5.27 for MC and 5.45 for SC cheeses on d 1 (data not shown). These differences could be due to faster and continued growth of starter culture in MC cheeses during cheddaring and milling compared to SC cheeses, where a pH drop (after a pH of 5.5) was extremely slow (data not shown). This may have an effect on the amount of residual coagulating enzymes in the cheese, which is dependent on the $\mathrm{pH}$ of the cheese $[8,19] . \mathrm{pH}$ of cheese influences proteolytic changes, which are considered to be the most important biochemical event during the ripening of many cheese varieties. Yun et al. $[46,50]$, however, did not observe any differences in proteolysis and meltability of Mozzarella cheeses milled at $\mathrm{pH}$ ranging from 5.40-5.10. According to these authors, differences in the milling $\mathrm{pH}$ alone will not result in variations in the functional characteristics or in proteolysis during storage. 

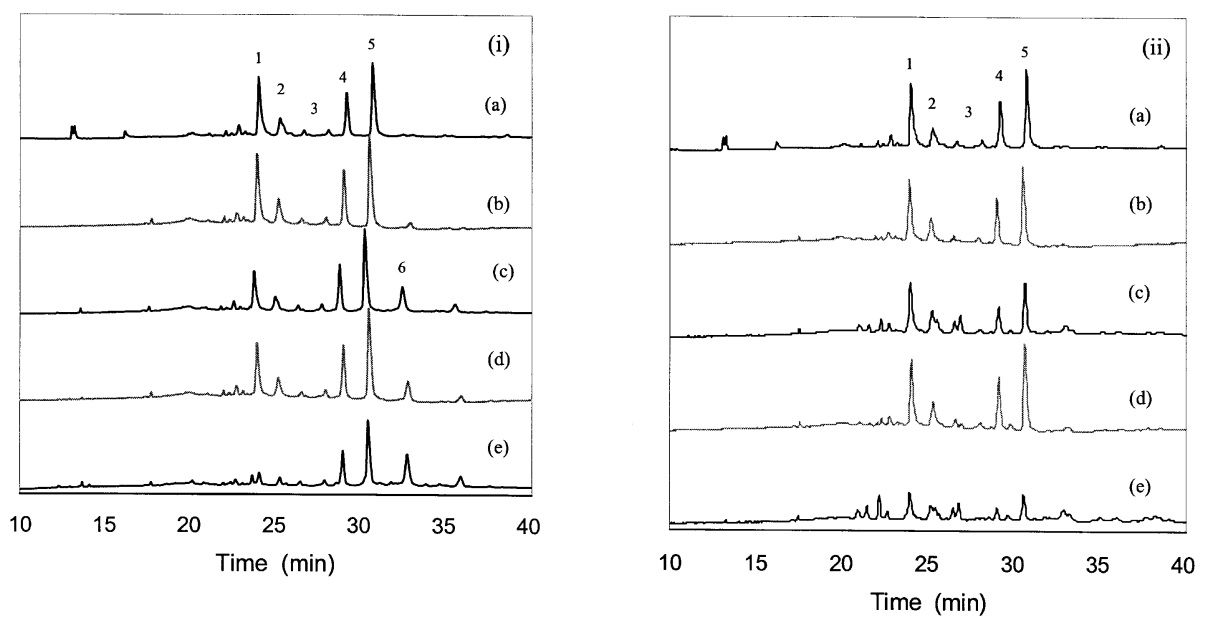

Figure 1. Capillary electrophoretogram of Mozzarella cheese made using mixed starter culture and coagulating enzyme (i) chymosin or (ii) Cryphonectria parasitica protease. $\mathrm{a}=$ milk sample; b, $\mathrm{c}=$ Mozzarella cheese made with $1 \times$ level of the coagulating enzyme on $\mathrm{d} 1$ and $\mathrm{d} 30$, respectively; $\mathrm{d}, \mathrm{e}=$ Mozzarella cheese made with the $6 \times$ level of the coagulating enzyme on $\mathrm{d} 1$ and $\mathrm{d} 30$, respectively. Migration of the intact proteins and hydrolysis products is indicated by the following numbers: $1=\alpha_{\mathrm{s} 1}$-casein, $2=\alpha_{\mathrm{s} 1}$-casein 9P, $3=\beta$-casein, $4=\beta$-casein A1, $5=\beta$-casein A2, $6=\alpha_{\mathrm{s} 1}$-casein $\mathrm{f}_{(24-199)}$.

\subsection{Proteolysis in cheese}

The capillary electrophoretograms of the mixed culture cheeses made with chymosin or protease from Cryphonectria parasitica are illustrated in Figure 1. The percent corrected peak areas were used for calculating the hydrolysis of $\alpha_{\mathrm{s}}$-casein and $\beta$-casein. The figure clearly showed that as the age of the cheese increased there was a corresponding decrease in the peak area for $\alpha_{\mathrm{s}}$-casein and $\beta$-casein in the experimental cheeses. On $\mathrm{d} 1$, the electrophoretogram of the cheeses was similar to that of milk, but as the cheeses aged there was a decrease in the peak area of $\alpha_{s}$-casein in case of chymosin cheeses and both caseins ( $\beta$-casein and $\alpha_{\mathrm{s}}$-casein) in case of cheeses made with CP protease. For chymosin cheeses, the disappearance of the $\alpha_{\mathrm{s}}$-casein peak appeared to be well correlated with the appearance of the fraction 24-199 of $\alpha_{\mathrm{s} 1}$-casein (Figs. 1, 2 and 4). Also, it is evi- dent from Figure 1 that the pattern of casein breakdown (as observed by several different peaks on electrophoretogram on d 30) was different in cheeses made with $\mathrm{SC}$ or MC using chymosin or CP protease.

\subsubsection{Breakdown of casein fractions}

Hydrolysis of $\alpha_{\mathrm{s}}$-casein was significantly higher $(P \leq 0.05)$ in cheeses made with chymosin compared to those made with CP protease (Tab. II and Fig. 2). Similarly, $6 \times$ cheeses also showed significantly higher $(P \leq 0.05)$ hydrolysis of $\alpha_{\mathrm{s}}$-casein compared to $1 \times$ cheeses (Tab. II; Fig. 2). Culture also had a significant effect $(P \leq 0.05)$ on the degradation of $\alpha_{\mathrm{s}}$-casein as did the interactions between culture $\times$ enzyme, culture $\times$ level, enzymexlevel, culture $\times$ time, enzymextime, level $\times$ time, and culture $\times$ enzymextime. Effect of other higher order interactions was, however, not significant $(P>0.05)$ (Tab. II). 

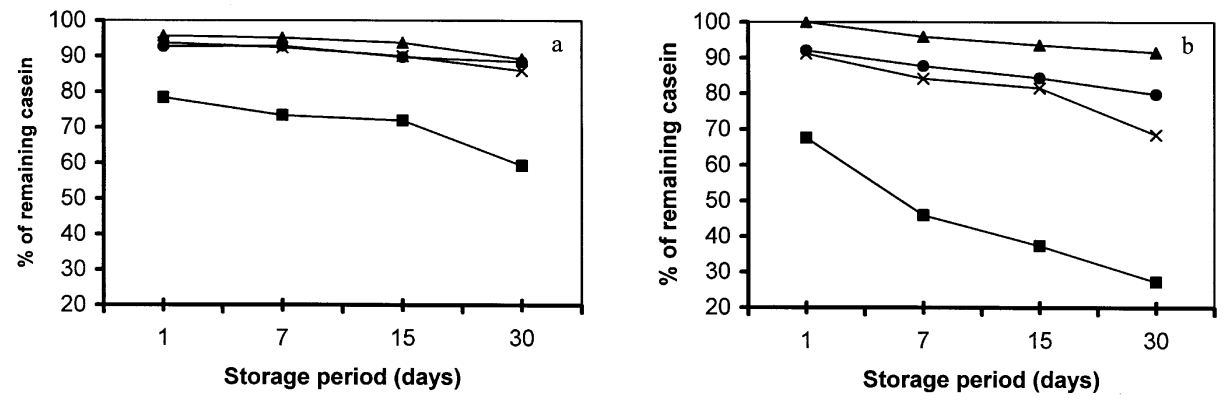

Figure 2. Effect of starter culture and type and level of coagulating enzyme on $\alpha_{\mathrm{s}}$-casein hydrolysis during storage $\left(4^{\circ} \mathrm{C}\right)$ of Mozzarella cheese. $\mathrm{a}=$ cheeses made with single culture and $\mathrm{b}=$ cheeses

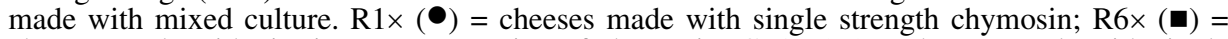
cheeses made with six times concentration of chymosin; $\mathrm{CP} 1 \times(\mathbf{\Delta})=$ cheeses made with single strength Cryphonectria parasitica; CP6 $(\times)=$ cheeses made with six times Cryphonectria parasitica.

Among the various treatments, maximum hydrolysis of $\alpha_{\mathrm{s}}$-casein was observed in MC cheeses made with $6 \times$ chymosin (approximately 70\%), followed by SC cheeses made with $6 \times$ chymosin (approximately $40 \%$ ) on d 30 (Fig. 2). In case of $1 \times$ cheeses, the degradation was lower than in $6 \times$ cheeses. Higher hydrolysis of $\alpha_{s}$-casein for $6 \times$ cheeses could be due to the higher concentration of the residual coagulating enzyme in these cheeses. Chymosin caused more degradation of $\alpha_{\mathrm{s}}$-casein as compared to Cryphonectria parasitica protease. Also, the degradation of $\alpha_{\mathrm{s}}$-casein was higher in MC cheeses compared to SC cheeses (Fig. 2). Results of our study are similar to other studies, where chymosin has been shown to hydrolyze $\alpha_{\mathrm{s}}$-casein but was found to have almost no effect on $\beta$-casein [8, 10, 48, 49]. Chymosin predominantly cleaves leu-X and phe- $X$ bonds but degrades $\alpha_{s}$-casein in cheese much more extensively than $\beta$-casein [44]. De Jong [10] reported negligible hydrolysis of $\alpha_{\mathrm{s}}$-casein in chymosinfree cheeses. Faster proteolysis (Figs. 2 to 5) in MC cheeses could be attributed to their lower $\mathrm{pH}$ compared to SC cheeses because of greater residual chymosin activity at lower $\mathrm{pH}[8,19,25]$. It may also be due to the activity of the starter culture, which is known to be proteolytically active during the initial stages of cheese ripening [12]. In addition, Lb. helveticus is more proteolytic than St. thermophilus [17, 18, $20,31,32]$. Often, most of the proteolysis contributed by the starter culture occurs after the residual coagulant retained in the cheese first hydrolyzes casein [12, 19, 33].

Breakdown of $\alpha_{\mathrm{s} 1}$-casein results in the formation of two fractions viz. $\mathrm{f}_{(1-23)}$ and $f_{(24-199)}$. Appearance of the fraction $f_{(24-199)}$ of $\alpha_{s 1}$-casein was therefore monitored to countercheck if the hydrolysis of $\alpha_{\mathrm{s}}$-casein was correlated with the formation and accumulation of the fraction $\alpha_{\mathrm{s} 1}$-casein $\mathrm{f}_{(24-199)}$. Similar to the hydrolysis of $\alpha_{\mathrm{s}}$-casein, significant differences $(P \leq 0.05)$ were observed in the appearance of $\alpha_{\mathrm{s} 1}$-casein $\mathrm{f}_{(24-199)}$ in cheeses made with different types of starter culture and enzymes at different levels (Figs. 2 and 4). Differences were also significant $(P \leq 0.05)$ as the cheeses aged. All of the two-way interactions, namely culturexenzyme, culture $\times$ level, enzymexlevel, culture $\times$ time, enzymextime, and level xtime, and the interactions between culture $\times$ enzymextime were significant $(P \leq 0.05)$ (Tab. II). Appearance of this fraction was the highest (Fig. 4) in MC cheese with $6 \times$ chymosin (average peak area of approximately 17) followed by that in SC cheeses with 
Table II. Analysis of variance for $\alpha_{\mathrm{s}}$-casein, $\beta$-casein, soluble protein, meltability, and creep test.

\begin{tabular}{|c|c|c|c|c|c|}
\hline & \multicolumn{5}{|c|}{$\mathrm{F}$-values for } \\
\hline & $\% \alpha_{\mathrm{s}}$-casein & $\% \beta$-casein & $\begin{array}{l}\% \text { Soluble } \\
\text { protein }\end{array}$ & $\begin{array}{c}\text { Melt area } \\
\left(\mathrm{mm}^{2}\right)\end{array}$ & Creep (30 s) \\
\hline Culture $^{1}$ & $72.45 * * *$ & $42.83 * * *$ & $220.98 * * *$ & $428.41 * * *$ & $468.33 * * *$ \\
\hline Enzyme $^{2}$ & $227.45^{* * *}$ & $75.48 * * *$ & $5.38^{*}$ & $17.48^{* * *}$ & $0.24 \mathrm{NS}$ \\
\hline Culture×Enzyme & $27.63 * * *$ & $59.15^{* * *}$ & $6.59^{*}$ & $19.02 * * *$ & $14.76 * * *$ \\
\hline Level $^{3}$ & $299.96 * * *$ & $24.54 * * *$ & $122.07 * * *$ & $10.54 * * *$ & $8.77 * * *$ \\
\hline Level $\times$ Culture & $50.84 * * *$ & $14.48 * * *$ & $60.98 * * *$ & $4.40^{*}$ & $1.58 \mathrm{NS}$ \\
\hline Level×Enzyme & $97.93 * * *$ & $27.74 * * *$ & $6.96^{* * * *}$ & $0.35^{\mathrm{NS}}$ & $0.51^{\mathrm{NS}}$ \\
\hline Culture $\times$ Enzyme $\times$ Level & $5.12^{*}$ & $14.07 * * *$ & $6.13 * *$ & $2.14 \mathrm{NS}$ & $0.06^{\mathrm{NS}}$ \\
\hline $\mathrm{Age}^{4}$ & $30.55^{* * *}$ & $36.89 * * *$ & $73.57 * * *$ & $116.63^{* * *}$ & $376.39 * * *$ \\
\hline Age $\times$ Culture & $5.44 * * *$ & $9.46^{* * *}$ & $30.65 * * *$ & $30.31 * * *$ & $10.49 * * *$ \\
\hline Age $\times$ Enzyme & $2.09 \mathrm{NS}$ & $10.78 * * *$ & $2.61 \mathrm{NS}$ & $1.64 \mathrm{NS}$ & $0.22 \mathrm{NS}$ \\
\hline Age $\times$ Culture $\times$ Enzyme & $0.82 \mathrm{NS}$ & $5.82 * * *$ & $3.22 *$ & $1.68^{\mathrm{NS}}$ & $1.10^{\mathrm{NS}}$ \\
\hline Age $\times$ Level & $7.28 * * *$ & $2.79^{*}$ & $17.10^{* * *}$ & $1.90^{\mathrm{NS}}$ & $5.09 * * *$ \\
\hline Age $\times$ Level $\times$ Culture & $1.49^{\mathrm{NS}}$ & $3.05^{*}$ & $8.70^{* * *}$ & $0.78^{\mathrm{NS}}$ & $0.49^{\mathrm{NS}}$ \\
\hline Age $\times$ Level $\times$ Enzyme & $1.73^{\mathrm{NS}}$ & $1.57 \mathrm{NS}$ & $1.86^{\mathrm{NS}}$ & $0.39^{\mathrm{NS}}$ & $0.76^{\mathrm{NS}}$ \\
\hline $\begin{array}{l}\text { Age } \times \text { Cul- } \\
\text { ture } \times \text { Enzyme } \times \text { Level }\end{array}$ & $0.79 \mathrm{NS}$ & $1.07 \mathrm{NS}$ & $2.26 \mathrm{NS}$ & $0.20^{\mathrm{NS}}$ & $0.39 \mathrm{NS}$ \\
\hline
\end{tabular}

*Significant at $P<0.05 ;{ }^{* *}$ significant at $P<0.01$; ${ }^{* * *}$ significant at $P<0.001$; ${ }^{\text {NS }}$ not significant at $P>0.05$.

${ }^{1}$ There were two types of culture (single or mixed culture).

2 There were two types of enzymes (chymosin or sure curd).

3 There were two levels of additions $(1 \times$ or $6 \times$ ).

${ }^{4}$ Cheeses were analyzed on $\mathrm{d} 1,7,15$, and 30 .

$6 \times$ chymosin (average peak area of approximatelyn 11). Results also indicated that in the case of chymosin cheeses at $6 \times$ level, the appearance of the fraction was faster and the effect was again found to be higher in MC cheeses as compared to the SC cheeses throughout the storage period. As the concentration of $\alpha_{\mathrm{s}}$-casein decreased in the various cheeses, initially there was a corresponding increase in the appearance of $\alpha_{\mathrm{s} 1}$-casein $\mathrm{f}{ }_{(24-199)}$ (Figs. 2 and 4). However, due to the further hydrolysis of $\mathrm{f}_{(24-199)}$ by residual chymosin or starter culture enzymes in some cheeses, the increase in the peak area was not as steep as it was initially, and in some cases even a decrease in the peak area was observed after $15 \mathrm{~d}$ storage period (Fig. 4b).

Hydrolysis of $\beta$-casein showed a similar pattern as that observed for $\alpha_{\mathrm{s}}$-casein. There was a significant effect $(P \leq 0.05)$ of culture, enzyme, level, and age (Tab. II). In general, the hydrolysis of $\beta$-casein was higher in cheeses made with MC (approximately 23\%), CP (approximately 24\%), and 6x (approximately 21\%) compared to those made with SC (approximately 11\%), chymosin (approximately 9\%), and $1 \times$ (approximately 12\%), respectively (data not shown). Age of the cheese also had a significant effect on the hydrolysis of $\beta$-casein and the trend was 

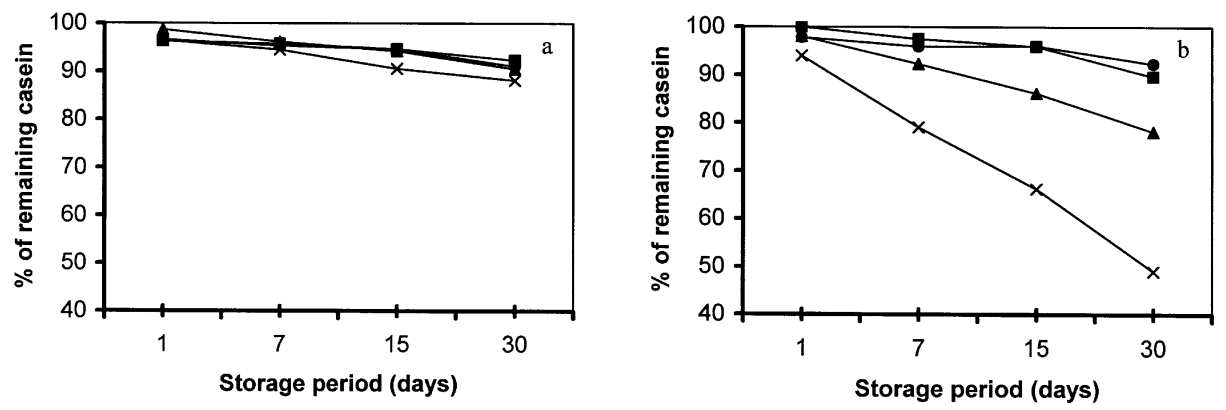

Figure 3. Effect of starter culture and type and level of coagulating enzyme on $\beta$-casein hydrolysis during storage $\left(4^{\circ} \mathrm{C}\right)$ of Mozzarella cheese. $\mathrm{a}=$ cheeses made with single culture and $\mathrm{b}=$ cheeses made with mixed culture. R1× $(\bullet)=$ cheeses made with single strength chymosin; R6× $(\boldsymbol{\bullet})=$ cheeses made with six times concentration of chymosin; $\mathrm{CP} 1 \times(\mathbf{\Delta})=$ cheeses made with single strength Cryphonectria parasitica; CP6 $(\times)=$ cheeses made with six times Cryphonectria parasitica.
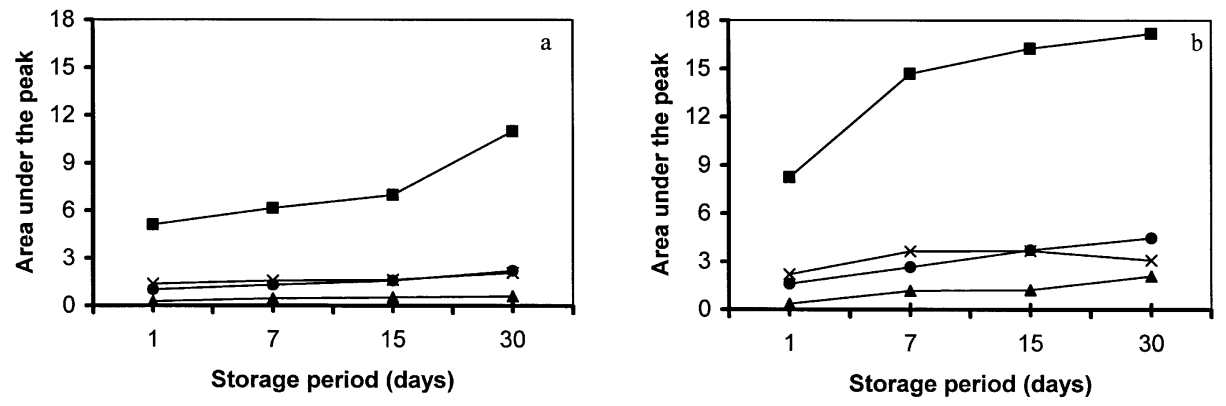

Figure 4. Effect of starter culture and type and level of coagulating enzyme on $f_{(24-199)}$ of $\alpha_{\mathrm{s} 1}$-casein during storage $\left(4^{\circ} \mathrm{C}\right)$ of Mozzarella cheese. $\mathrm{a}=$ cheeses made with single culture and $\mathrm{b}=$ cheeses made with mixed culture. $\mathrm{R} 1 \times(\bullet)=$ cheeses made with single strength chymosin; R6 $\times(\boldsymbol{\square})=$ cheeses made with six times concentration of chymosin; $\mathrm{CP} 1 \times(\mathbf{\Lambda})=$ cheeses made with single strength Cryphonectria parasitica; $\mathrm{CP} 6 \times(\times)=$ cheeses made with six times Cryphonectria parasitica.

similar throughout storage as observed for $\alpha_{\mathrm{s}}$-casein. Also, the interactions between culturexenzyme, culture $\times$ level, enzymexlevel, culture $\times$ time, enzymextime, level $\times$ time, and culture $\times$ enzymextime were significant (Tab. II). Among the treatments, maximum hydrolysis of $\beta$-casein was observed in MC cheeses made with $6 \times$ CP (approximately $51 \%$ ) followed by that in $\mathrm{MC}$ cheeses made with $1 \times \mathrm{CP}$ (approximately 22\%) (Fig. 3b).
In contrast to $\alpha_{\mathrm{s}}$-casein, $\beta$-casein was hydrolyzed to a greater extent when $\mathrm{CP}$ protease was used as the coagulating enzyme, supporting previous observations of Yun et al. [48] and Bogenrief and Olson [4], who reported that coagulating enzyme from $\mathrm{CP}$ was more specific to $\beta$-casein hydrolysis in Mozzarella and Cheddar cheeses. Protease from CP is also heat sensitive (more than chymosin) but if it survives the heat treatment, it is highly 

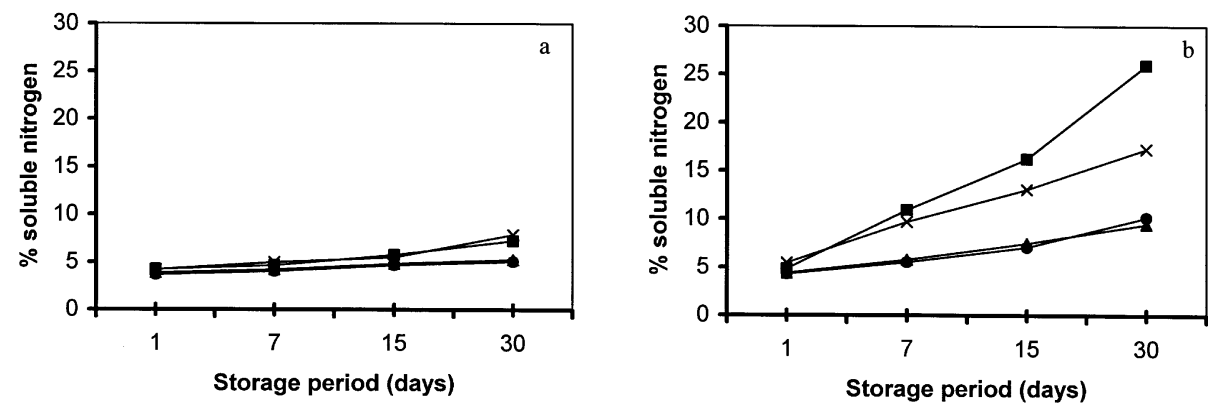

Figure 5. Effect of starter culture and type and level of coagulating enzyme on percent soluble protein of the total protein present in Mozzarella cheese during storage at $4{ }^{\circ} \mathrm{C}$. a $=$ cheeses made with single culture and $\mathrm{b}=$ cheeses made with mixed culture. $\mathrm{R} 1 \times(\bullet)=$ cheeses made with single strength chymosin; R6 $\times(\boldsymbol{\square})=$ cheeses made with six times concentration of chymosin; $\mathrm{CP} 1 \times(\mathbf{\Lambda})=$ cheeses made with single strength Cryphonectria parasitica; $\mathrm{CP} 6 \times(\times)=$ cheeses made with six times Cryphonectria parasitica.

proteolytic [43]. Though this enzyme degraded both $\alpha_{\mathrm{s} 1}$-casein and $\beta$-casein in pure solutions, it more specifically hydrolyzed $\beta$-casein in Gouda [43], Cheddar [4, 34] and Mozzarella [13, 48] cheeses.

Hydrolysis of $\beta$-casein in cheeses made with different types of culture followed the trends similar to those of $\alpha_{\mathrm{s}}$-casein, though the extent of hydrolysis was lower. Cheeses made with MC showed much higher proteolysis compared to those made with SC cheeses, signifying the role of proteolytic enzymes of starter bacteria. It has been also reported that the retention of chymosin depends on the draining and milling $\mathrm{pH}$, but retention of microbial coagulants was not influenced by the acidification rate during cheese making $[8,19]$. Thus, the differences in the hydrolysis may not be $\mathrm{pH}$-dependent because unlike chymosin, the retention of microbial coagulants is not $\mathrm{pH}$-dependent $[8,19]$.

\subsubsection{Soluble protein}

Soluble protein increased in all the samples during storage (Fig. 5) and the differences were significant $(P \leq 0.05)$ for culture, enzyme, level, and time. Interactions between culturexenzyme, culturexlevel, enzymexlevel, culture $\times$ time, enzyme $\times$ time, level $\times$ time, and culture $\times$ enzyme $\times$ time were also significant (Tab. II). Soluble protein was significantly higher in MC cheeses compared to SC cheeses, and the differences were higher for the level of enzyme compared to the type of enzyme. Highest soluble nitrogen was found in MC cheeses made with $6 \times$ chymosin followed by MC cheeses made with $6 \times$ level of $\mathrm{CP}$ protease (Fig. 5b). Higher soluble nitrogen in MC cheeses can also be attributed to the complementary proteolytic effects of the starter culture, mainly $L b$. helveticus and the residual coagulating enzymes $[18,32]$.

The coagulating enzyme from chymosin and Cryphonectria parasitica showed similar levels of soluble nitrogen initially; but towards the end of storage, higher soluble nitrogen was observed for cheeses made with chymosin. This could have happened because, though chymosin acts preferentially on $\alpha_{\mathrm{s}}$-casein and $\mathrm{CP}$ protease on $\beta$-casein, they both hydrolyze total casein to a similar extent. Higher values of soluble nitrogen in the chymosin cheeses towards the end of storage may be attributed to the fact that chymosin and lactobacilli act synergistically and produce more free amino acid [18]. On the 

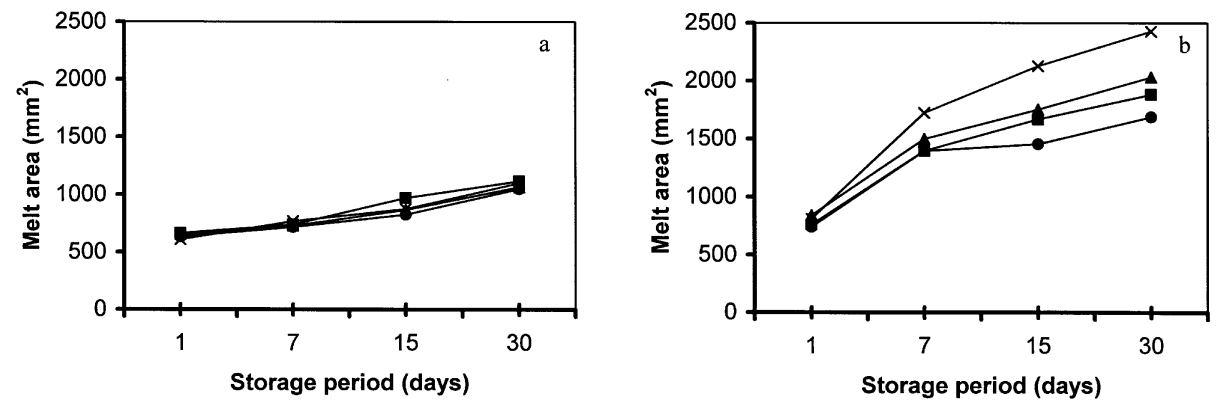

Figure 6. Effect of starter culture and type and level of coagulating enzyme on the meltability during storage $\left(4^{\circ} \mathrm{C}\right)$ of Mozzarella cheese as measured by Schreiber test. $\mathrm{a}=$ cheeses made with single culture and $\mathrm{b}=$ cheeses made with mixed culture. $\mathrm{R} 1 \times(\bullet)=$ cheeses made with single strength chymosin; $\operatorname{R} 6 \times(\mathbf{\square})=$ cheeses made with six times concentration of chymosin; $\mathrm{CP} 1 \times(\mathbf{\Delta})=$ cheeses made with single strength Cryphonectria parasitica; $\mathrm{CP} 6 \times(\times)=$ cheeses made with six times Cryphonectria parasitica.

contrary, Vanderpoorten and Weckx [43] observed that enzyme from Cryphonectria parasitica leads to higher NPN compared to chymosin. These differences in observations may be because the combined effect of the starter culture and the coagulating enzyme may not have been considered or because some of the enzyme may have been inactivated during cooking and stretching in our study. As described earlier, CP protease is more heat sensitive than chymosin [40]. Various researchers have reported that the coagulant is responsible for the formation of large peptides, while smaller peptides and free amino acids are produced by starter bacteria, possibly from peptides initially produced by the coagulant [33]. Further, Lb. helveticus is reported to have higher aminopeptidase, proline-iminopeptidase, and aminopeptidase-P activity [31, 32] and chymosin seems to complement this activity $[17,18]$. These reasons may have also been responsible for the higher soluble nitrogen in the chymosin cheeses as compared to the $\mathrm{CP}$ cheeses in our study. Higher soluble nitrogen in $6 \times$ cheeses may be assumed to be a direct effect of the higher concentration of the coagulating enzyme on proteolysis.

\subsection{Meltability of cheese}

\subsubsection{Schreiber test}

Meltability of all the cheeses increased during storage (Fig. 6) and it was significantly $(P \leq 0.05)$ higher for $\mathrm{MC}$ cheeses than SC cheeses (Tab. II). Average increase in area for MC cheeses in $30 \mathrm{~d}$ was approximately $230 \%$ compared to approximately $80 \%$ for SC cheeses when they were compared with the average area of the SC cheeses on d 1 (Fig. 6). Effects of the type of enzyme and the level of addition were statistically significant $(P \leq 0.05)$, but the differences were not as great for SC or MC cheeses (Tab. II and Fig. 6). The average increase in area of chymosin and $\mathrm{CP}$ cheeses was approximately 135 and $170 \%$, respectively (data not shown). Interactions between culturexenzyme, culture $\times$ level, enzyme $\times$ level, culture $\times$ time, enzymextime, level $\times$ time and culture $\times$ enzymextime were also significant (Tab. II).

Meltability also increased with an increase in the age of the cheese $(P \leq 0.05)$. Increase in meltability of cheese has been attributed to proteolysis occurring in cheese during storage. During storage, the protein matrix absorbs moisture that was 
held within the fat serum channels. This allows the re-arrangement of proteins, which increases hydration in the surrounding matrix [6]. Then, as the proteins become more hydrated, they flow more easily when heated and thus increase the meltability of cheeses [26].

Overall, meltability of our cheeses was better correlated to the hydrolysis of $\beta$-casein $\left(r^{2}=0.72\right)$ or soluble nitrogen $\left(r^{2}=\right.$ $0.76)$ than to the hydrolysis of $\alpha_{\mathrm{s}}$-casein $\left(\mathrm{r}^{2}=0.36\right)$ (data not shown), which is in agreement with Cheddar cheese studies of Bogenrief and Olson [4], and Creamer and Olson [7]. In our study, we observed that on $\mathrm{d} 30$, the maximum hydrolysis of $\alpha_{\mathrm{s}}$-casein was approximately 50\% for SC cheeses and approximately $70 \%$ for MC cheeses made with $6 \times$ chymosin, but there were larger differences in meltability of these cheeses (Figs. 3 and 6). Additionally, cheeses made with $\mathrm{CP}$ protease mainly hydrolyzed $\beta$-casein and had an average increase in melt area of approximately $170 \%$ compared to $135 \%$ (data not shown) for the cheeses made with chymosin (which primarily hydrolyzed $\alpha_{\mathrm{s}}$-casein). This implies that not just the hydrolysis of caseins is important, but the type of hydrolysis is also important. $\alpha_{\mathrm{s}}$-Casein is the primary structural protein in cheese, however, breakdown of the same appears to be more related to the softness of the cheese than the flowing of cheese. Contrarily, breakdown of $\beta$-casein appears to improve the flow of cheese and therefore cheeses with greater $\beta$-casein breakdown showed increased melt in our study.

Higher level of coagulating enzymes resulted in increased melt of the cheeses (Fig. 6). This is due to the direct effect of higher proteolysis caused by the higher concentration and activity of coagulating enzymes retained in these cheeses.

Higher meltability of MC cheeses compared to SC cheeses may also be because of higher proteolysis caused by $L b$. helveticus in the mixed culture [14]. Use of such proteolytic cultures has also been shown to increase the meltability of Mozzarella cheese compared to those prepared with less proteolytic starter cultures [31, 32].

Further, bacterial channels and their arrangement in a cheese protein matrix, along with the hydration of caseins, may have contributed to higher melt in the MC cheeses as previously explained by McMahon and Oberg [27] in describing the role of fat-serum channels. After stretching, the live starter bacterial population was approximately $2 \log$ s higher in $\mathrm{MC}$ cheeses than in SC cheeses (data not shown). Thus, the bacterial cells may be acting as fillers in $\mathrm{MC}$ cheeses, and providing more proteolytic enzymes and resulting in an increase in melt.

\subsubsection{Creep test}

Creep test measures the deformation of cheese under constant force for a period of time. This test is a measure of the softness of cheeses unlike the Schreiber test, which measures the flowability of cheeses. Average values of decrease in height of the samples (after $30 \mathrm{~s}$ ) are shown in Figures 7a and $7 b$.

Culture and type and level of enzymes had a significant effect $(P \leq 0.05)$ on the softness of cheeses. MC cheeses showed a greater fall in height compared to cheeses made with SC, and the trend was the same throughout storage. On d 30 of storage, fall in height of $\mathrm{MC}$ and $\mathrm{SC}$ cheeses was approximately 73 and $43 \%$, respectively, considering the original height of the samples as 100. MC and SC cheeses made with chymosin or CP protease exhibited a similar fall in height, whereas cheese with the two levels of enzymes had comparatively greater differences. Decrease in height observed with chymosin and CP cheeses was approximately $60 \%$, but for $1 \times$ and $6 \times$ cheeses, it was approximately 54 and $62 \%$, respectively (data not shown). Age of the cheese also had a significant effect on the softness of all cheeses. This may be attributed to the proteolysis occurring during 

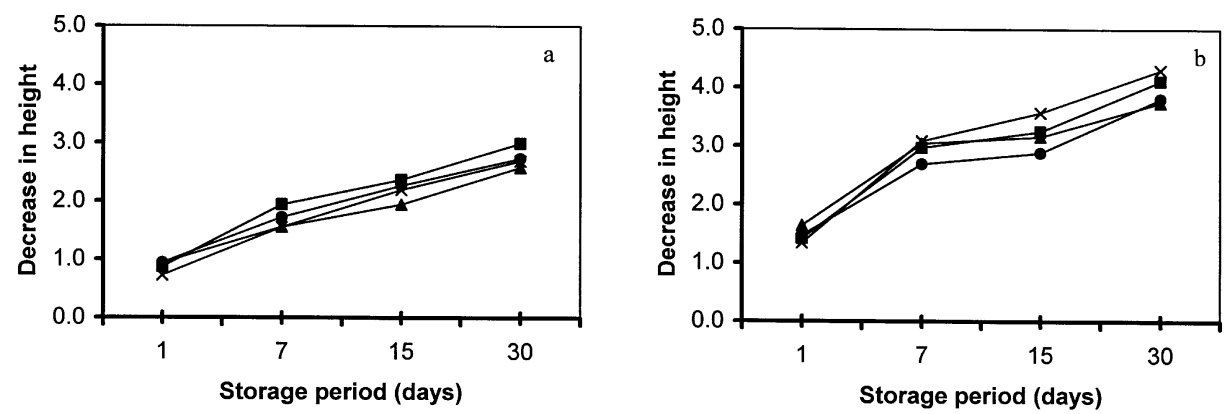

Figure 7. Effect of starter culture, and type and level of coagulating enzyme on the meltability during storage $\left(4^{\circ} \mathrm{C}\right)$ of Mozzarella cheese as measured by Creep test $(30 \mathrm{~s}) . \mathrm{a}=$ cheeses made with single culture and $\mathrm{b}=$ cheeses made with mixed culture. $\mathrm{R} 1 \times(\bullet)=$ cheeses made with single strength chymosin; $\operatorname{R} 6 \times(\mathbf{\square})=$ cheeses made with six times concentration of chymosin; $\mathrm{CP} 1 \times(\mathbf{\Delta})=$ cheeses made with single strength Cryphonectria parasitica; $\mathrm{CP} 6 \times(\times)=$ cheeses made with six times Cryphonectria parasitica.

storage. Interactions between culture $\times$ enzyme, culture $\times$ level, enzymexlevel, culture $\times$ time, enzymextime, level $\times$ time, and culture $\times$ enzyme $\times$ time were also significant (Tab. II).

These observations highlighted a very important aspect of this study: softness and flowability of cheese are two different aspects. The type of coagulant (CP protease vs. chymosin) has comparatively less influence on the softness of cheese (Fig. 7), but it had greater influence on the meltability of the cheese (Fig. 6). Thus, cheeses made with chymosin were equally soft but were less flowable compared to the $\mathrm{CP}$ cheeses. The softness and flow are two different phenomena. We observed that when the intact caseins (either $\alpha_{\mathrm{s}}$ - or $\beta$-caseins) are hydrolyzed, it first affects the cheese protein structure and makes it softer, but the melting is not directly related to this cheese softness alone. Melting is largely governed by the flow of cheese, which appears to be better in cheeses made with coagulating enzyme that either speeds up proteolysis of $\beta$-caseins and/or generates smaller peptides from the first breakdown products of $\alpha_{\mathrm{s}}$ - or $\beta$-caseins, mainly by the starter culture proteinases and peptidases that make softer cheese to flow. De Jong [10] reported that the softening of cheeses was more often correlated to the amount of the intact $\alpha_{\mathrm{s}}$-casein. This could possibly be because the breakdown products of caseins are largely water-soluble and do not contribute to the protein matrix.

Further, with an increased concentration of coagulating enzyme, there will be faster degradation of the already hydrolyzed larger protein fraction $\mathrm{f}_{(24-199)}$. This may have made cheese more flowable. The differences in MC and SC cheeses could be due to more activity of residual coagulating enzyme (due to confounding effects of $\mathrm{pH}$ in these cheeses, as explained earlier, or due to the combined action of starter culture and the coagulating enzymes) rendering faster proteolysis in MC cheeses (Fig. 5).

\section{CONCLUSIONS}

Cheeses made with MC had higher moisture content than those made with SC. This could be due to the faster rate of acid production in the former cheeses. There were, however, no significant differences 
in moisture content of cheeses made with a particular type or level of coagulating enzyme. Chymosin cheeses showed greater hydrolysis of $\alpha_{\mathrm{s}}$-casein, whereas Cryphonectria parasitica cheeses showed a greater hydrolysis of $\beta$-casein. Hydrolysis of both the caseins $\left(\alpha_{\mathrm{s}}\right.$ or $\left.\beta\right)$ was higher in MC cheeses and at $6 \times$ level of enzyme addition. Soluble nitrogen was also higher in $\mathrm{MC}$ cheeses and the differences were higher in $6 \times$ cheese compared to SC cheeses with $1 \times$ level of enzyme addition, respectively. Differences were, however, not very high for the type of enzyme.

Increase in the melt area as measured by the modified Schreiber test was again higher for MC cheeses and the $6 \times$ level of enzyme addition. CP cheeses showed a highest increase in melt area as against chymosin cheeses. Meltability as measured by Creep test indicated that MC cheeses softened to a greater extent compared to SC cheeses and that $6 \times$ cheeses softened better compared to $1 \times$ cheeses. Differences between chymosin and $\mathrm{CP}$ protease were, however, not significant. This is an important observation because it indicates that the type of proteolysis is important in determining the melt characteristics, as cheeses with similar softening may flow differently. Meltability of Mozzarella cheese was better correlated to hydrolysis of $\beta$-casein and was comparable to soluble nitrogen but least to hydrolysis of $\alpha_{\mathrm{s}}$-casein.

\section{ACKNOWLEDGEMENTS}

The authors thank Dr. M. Strickland, Research Associate of Utah State University for her help with capillary electrophoresis. The authors are also indebted to Dr. K. Muthukumarappan of the Agricultural and BioSystems Engineering Department of South Dakota State University for use of the melt test facilities and for providing some insight at the time of concluding our results.

\section{REFERENCES}

[1] Alverez R.J., Expectations of Italian cheese in the pizza industry, in: 23rd Proceeding Annual Marschall, Invitational Italian Cheese Seminar, Marschall Products-Miles Laboratories Inc., Madison, WI, USA Sept. 16-18, 1986, p. 130.

[2] AOAC, Official Methods of Analysis, 17th ed., AOAC Int., Gaithersburg, MD, USA, 2000.

[3] Atherton H.V., Newlander J.A., Chemistry and testing of dairy products, 4th ed., AVI Publishing Co. Inc., Westport, CT, USA, 1977.

[4] Bogenrief D.D., Olson N.F., Hydrolysis of $\beta$-casein increases Cheddar cheese meltability, Milchwissenschaft 50 (1995) 678-682.

[5] Broadbent J.R., Strickland M., Weimer B.C., Johnson M.E., Steele J.L., Peptide accumulation and bitterness in Cheddar cheese made using single-strain Lactococcus lactis starters with distinct proteinase specificities, J. Dairy. Sci. 81 (1998) 327-337.

[6] Creamer L.K., Water absorption by renneted casein micelles, Milchwissenschaft 40 (1985) 589-591.

[7] Creamer L.K., Olson N.F., Rheological evaluation of maturing Cheddar cheese, J. Food Sci. 47 (1982) 631-636, 646.

[8] Creamer L.K., Lawrence R.C., Gilles J., Effect of acidification of cheese milk on the resultant Cheddar cheese, N.Z.J. Dairy Sci. Technol. 20 (1985) 185-203.

[9] Dave R.I., McMahon D.J., Oberg C.J., Broadbent J.R., Influence of coagulant concentration on proteolysis, meltability and rheology of 0,10 and $20 \%$ fat containing Mozzarella cheeses made using direct acidification, J. Dairy Sci. (2003) In Press.

[10] de Jong L., Protein breakdown in soft cheese and its relation to consistency. 2. The influence of the rennet concentration, Neth. Milk Dairy J. 31 (1977) 314-327.

[11] Diefes H.A., Rizvi S.S.H., Bartsch J.A., Rheological behaviour of frozen and thawed low moisture part-skim Mozzarella cheese, J. Food Sci. 58 (1993) 764-769.

[12] Dulley J.R., The contribution of rennet and starter enzymes to proteolysis in cheese, Aust. J. Dairy Technol. 29 (1974) 65-69.

[13] Farkye N.L., Kiely L.J., Allshouse R.D., Kindstedt P.S., Proteolysis in Mozzarella cheese during refrigerated storage, J. Dairy Sci. 74 (1991) 1433-1438.

[14] Fecera R.M., Oberg C.J., McMahon D.J., Effect of proteolytic adjunct cultures on the 
physical properties of low fat Mozzarella cheese, in: Annual Meeting, Institute of Food Technologists, Anaheim, CA, USA, June 3-7, 1995.

[15] Fife R.L., McMahon D.J., Oberg C.J., Functionality of low fat Mozzarella cheese, J. Dairy Sci. 79 (1996) 1903-1910.

[16] Fox P.F., Guinee T.P., Cogan T.M., McSweeney P.L.H., Cheese rheology and texture, in: Fundamentals of Cheese Science, Aspen Publishers, Inc., Gaithersburg, MD, USA, 2000, pp. 305-333.

[17] Frey J.P., Marth E.H., Johnson M.E., Olson N.F., Peptidases and proteases of lactobacilli associated with cheese, Milchwissenschaft 41 (1986) 622-624.

[18] Hickey M.W., Hillier A.J., Jago G.R., Peptidase activity in lactobacilli, Aust. J. Dairy Technol. 38 (1983) 118-123.

[19] Holmes D.G., Duersch J.W., Ernstrom C.A., Distribution of milk clotting enzymes between curd and whey and their survival during Cheddar cheesemaking, J. Dairy Sci. 60 (1977) 862-869.

[20] Hong Y.H., Yun J.J., Barbano D.M., Larose K.L., Kindstedt P.S., Mozzarella cheese: Impact of three commercial strains on composition, proteolysis and functional properties, Aust. J. Dairy Technol. 53 (1998) 163-169.

[21] Kindstedt P.S., Functional properties of Mozzarella cheese on pizza: a review, Cult. Dairy Prod. J. 26 (3) (1991) 27-31.

[22] Kindstedt P.S., Effect of manufacturing factors, composition, and proteolysis on the functional characteristics of Mozzarella cheese, Crit. Rev. Food Sci. Nutr. 33 (1993) 167-187.

[23] Kindstedt P.S., Kosikowski F.V., Measurement of sodium chloride in cheese by a simple sodium ion electrode method, J. Dairy Sci. 67 (1984) 879-883.

[24] Kosikowski F.V., Mistry V.V., Analysis determination of soluble protein in cheese (Kjeldahl), in: Kosikowski F.V. (Ed.), Cheese and Fermented Milk Foods, Vol. II: Procedures and Analysis, 3rd ed. L. L. C., Westport, CT, USA 1997, pp. 223-224.

[25] Larsson K.I., Andren A., Affinity between chymosin and individual caseins at varying pH-values, Int. Dairy J. 7 (1997) 615 -618.

[26] McMahon D.J., Oberg C.J., Influence of fat, moisture, and salt on functional properties of Mozzarella cheese, Aust. J. Dairy Technol. 53 (1998) 98-101.

[27] McMahon D.J., Oberg C.J., Deconstructing Mozzarella, Dairy Ind. Int. 63 (1999) 23-26.
[28] Mistry V.V., Anderson D.L., Composition and microstructure of commercial full-fat and low-fat cheeses, Food Struct. 12 (1993) 259-266.

[29] Muthukumarappan K., Wang Y.C. Gunasekaran S., Modified Schreiber test for evaluation of Mozzarella cheese meltability, J. Dairy Sci. 82 (1999) 1068-1071.

[30] Oberg C.J., Broadbent J.R., Thermophilic starter cultures: another set of problems, J. Dairy Sci. 76 (1993) 2392-2406.

[31] Oberg C.J., Wang A., Moyes L.V., Brown R.J., Richardson G.H., Effects of proteolytic activity of thermolactic cultures on physical properties of Mozzarella cheese, J. Dairy Sci. 74 (1991) 389-397.

[32] Oberg C.J., Merrill R.K., Moyes L.V., Brown R.J., Richardson G.H., Effects of Lactobacillus helveticus culture on physical properties of Mozzarella cheese, J. Dairy Sci. 74 (1991) 4101-4107.

[33] O’Keeffe A.M., Fox P.F., Daly C., Proteolysis in Cheddar cheese: Role of coagulant and starter bacteria, J. Dairy Res. 45 (1978) 465-477.

[34] Olson N.F., Designing cheeses to meet market demands, Proc. Bienn. Cheese Ind. Conf. Utah State University, Logan, UT, USA, Aug. 20-22, 1996 (unnumbered).

[35] Pilcher S.W., Kindstedt P.S., Survey of Mozzarella cheese quality at restaurant end use, J. Dairy Sci. 73 (1990) 1644-1647.

[36] Poduval V.S., Mistry V.V., Manufacture of reduced fat Mozzarella cheese using ultrafiltered sweet buttermilk and homogenized cream, J. Dairy Sci. 82 (1999) 1-9.

[37] Radke-Mitchell L., Sandine W.E., Associative growth and differential enumeration of Streptococcus thermophilus and Lactobacillus bulgaricus: a review, J. Food Protect. 47 (1984) 245-248.

[38] Rowney M., Roupas P., Hickey M.W., Everett D.W., Factors affecting the functionality of Mozzarella cheese, Aust. J. Dairy Technol. 54 (1999) 94-102.

[39] SAS ${ }^{\circledR}$ User's Guide: Stastics, version 6.0, SAS Inst., Inc., Cary, NC, 1990.

[40] Thunnel R.K., Duersch J.W., Ernstrom C.A., Thermal inactivation of residual milk clotting enzymes in whey, J. Dairy Sci. 62 (1979) 373-377.

[41] Tunick M.H., Mackey K.L., Shieh J.J., Smith P.W., Cooke P., Malin E.L., Rheology and microstructure of low-fat Mozzarella cheese, Int. Dairy J. 3 (1993) 649-662.

[42] US Environmental Protection Agency, Method 6010a (Revision 1): Inductively 
coupled plasma-atomic emission spectroscopy, in: Test Methods for Evaluating Solid Waste, Vol. 1A: Laboratory Manual Physi$\mathrm{cal} /$ Chemical Methods, Office of Solid Waste and Emergency Response, US Environ. Prot. Agency, Washington, DC, USA, 1992.

[43] Vanderpoorten R., Weckx M., Breakdown of casein by rennet and microbial milk-clotting enzymes, Neth. Milk Dairy J. 26 (1972) 47-59.

[44] Visser S., Proteolytic enzymes and their action on milk proteins, Neth. Milk Dairy J. 35 (1981) 65-88.

[45] Wang Y.C., Muthukumarappan K., Ak M.M., Gunasekaran S., A device for evaluating melt/flow characterictics of cheeses, J. Text. Stud. 29 (1998) 43-55.

[46] Yun J.J., Barbano D.M., Kindstedt P.S., Mozzarella cheese: impact of milling $\mathrm{pH}$ on chemical composition and proteolysis, J. Dairy Sci. 76 (1993) 3629-3638.

[47] Yun J.J., Kiely L.J., Kindstedt P.S., Barbano D.M., Mozzarella cheese: impact of milling $\mathrm{pH}$ on functional properties, J. Dairy Sci. 76 (1993) 3639-3647.

[48] Yun J.J., Barbano D.M., Kindstedt P.S., Mozzarella cheese: impact of coagulant type on chemical composition and proteolysis, J. Dairy Sci. 76 (1993) 3648-3656.

[49] Yun J.J., Kiely L.J., Kindstedt P.S., Barbano D.M., Mozzarella cheese: impact of coagulant type on functional properties, J. Dairy Sci. 76 (1993) 3657-3663.

[50] Yun J.J., Barbano D.M., Larose K.L., Kindstedt P.S., Mozzarella cheese: impact of nonfat dry milk fortification on composition, proteolysis, and functional properties, J. Dairy Sci. 81 (1998) 1-8. 